\title{
ПРОБЛЕМА ФОРМИРОВАНИЯ МОТИВАЦИИ ДОСТИЖЕНИЙ СТУДЕНТОВ ГУМАНИТАРНЫХ ВУЗОВ
}

\author{
А.С. Милентьева \\ Московский гуманитарный университет
}

Аннотация: В статье раскрываются взаимосвязи иенностных ориентаций и мотивации достижений, важных для формирования личности учащихся, оптимизации работы студентов, раскрытия их потенциальных возможностей.

Ключевые слова: цуенностные ориентаџии, мотивачия, личность, студенты

\section{THE PROBLEM OF STUNENTS' MOTIVATION FORMATION OF HUMANITARIAN UNIVERSITIES}

\author{
A. S. Melentieva \\ Moscow University for the Humanities
}

Abstract: the article reveals the interrelationships of value orientations and motivation of achievements that are important for the formation of students 'personality, optimization of students' work, and disclosure of their potential opportunities.

Keywords: value orientations, motivation, personality, students

В процессе развития государства, общества и условий для жизни появляются все новые ценностные ориентации и мотивации, вследствие чего меняются и качества личности современных студентов. Формирование ценностных ориентаций и мотивации студентов является одной из важнейших частей развития личности. Ценностные ориентации являются отражением образа жизни современных студентов, ценности задают цели, к реализации которых мы стремимся.

Наряду с ценностными ориентациями значимое место в структуре личности занимает мотивация человека. Мотивация - это готовность индивида к определенной деятельности и готовность приложить усилия для достижения цели под влиянием внешних и внутренних факторов. Главная суть мотивации заключается в обязательном удовлетворении индивидуальных потребностей человека.

В настоящее время исследование ценностных ориентаций является весьма актуальным в связи с тем, что ценности, которые возникают в современном обществе - это показатель уровня культуры и отражение общественного поведения. Ценностные ориентации индивида рождают его цели, являются основой выбора его жизненного пути, а меняющиеся условия жизни оказывают прямое влияние на возникающие ценности.

Мы можем рассматривать ценности на индивидуальном уровне, тогда 
они будут выступать как основы мотивов, побуждающих людей к действиям в повседневной жизни, где мотив - это осознанное побуждение удовлетворить свои потребности, т.е. - это толчок и причина, по которой человек начинает чтото делать для достижения поставленной цели.

В 1914 г. появилась работа Э. Шпрангера «Формы жизни», в которой он выделил шесть типов личности в зависимости от их ценностных ориентации (Шпрангер, 2014), а затем Оллпорт, опираясь на модель Шпрангера, разработал подобную классификацию, представленную как черты ценностей (Оллпорт, 2015). Назовем основные характеристики типов личности.

I. Теоретическая - личность, направленная на поиск истины, познание. Рационален, руководствуется эмпирическими методами. Такой тип личности высоко интеллектуален, зачастую занят в области фундаментальной науки или философии.

II. Экономическая - личность, которая ищет для себя выгоду и пользу. Такие люди крайне практичны, заинтересованы в увеличении прибыли, заработке денег, предпочитают получать только «полезные» знания, которые смогут применить для достижения цели или иной выгоды. Большинство известных бизнесменов, техников и технологов являются личностями данного склада.

III. Эстетическая - такая личность в первую очередь заинтересована в красоте и гармонии. Такие люди воспринимают жизнь, как наслаждение, действуют ради себя и своего блага. Такие люди не всегда проявляют творческие способности, но склонны проявлять интерес к эстетическим сторонам жизни.

IV. Социальная - ценностью личности такого типа является любовь к людям. Такие люди считают любовь единственным уместным и гуманным подходом к жизни. Такие люди альтруистичны и религиозные ценности для этого типа личности особенно важны.

V. Политическая - для политического типа личности особенно важна власть. К данному типу относятся лидеры в любой области деятельности. Такие люди жаждут влияния, известности, славы и личной власти как таковой.

VI. Религиозная - это личность, заинтересованная в понимании мира, вселенской мудрости, познания человеческого предназначения. Такие люди могут самовыражаться различными путями, но рассматривают жизнь как единство мироздания и поиск высшего смысла.

Теоретики, решавшие эту задачу, высказали предположение, что измерение ценностей отражают основные проблемы, с которыми сталкивается та или иная социальная группа.

В каждом из нас присутствует несколько типов личности, но один или два преобладают над другими. Так, в зависимости от типов личности, которые выражаются через определенные ценности, мы можем определить наклонности личности и, возможную будущую профессию. 
Научные труды Московского гуманитарного университета

2020 № 6

Так,мывидим, чтоценностныеориентации-этопомощникисамоопределения личности, определяющие предназначения личности, склонности к развитию в разных областях деятельности. Ценностные ориентации индивида рождают его цели, являются основой выбора жизненного пути, а меняющиеся условия жизни оказывают прямое влияние на возникающие в процессе ценности.

...Успеваемость студентов зависит не только от общего интеллектуального развития и способностей к обучению, но также от интересов и мотивов, черт характера, темперамента, направленности личности, ее самосознания, уровня общего интеллектуального развития и многого другого. Но для оптимизации процесса обучения, для того, чтобы раскрыть потенциальные возможности учащихся необходимо создать условия для достойной работы и активного участия в образовательном процессе. А ценности - это инструмент, который покажет важные для обучающегося цели и условия - мотивы для достижения целей его деятельности.

Одна из основных потребностей студентов - общение. Общение стимулирует развитие дружеских отношений в коллективе, что способствует взаимоподдержке, обмену знаниями и опытом, а также поддержанию нормальной самооценки учащихся (Ансимова, Мишучкова, 2016).

Важна для студентов потребность в достижениях. Множество исследований показывают важность духовных потребностей студентов и их связь с эффективностью деятельности в процессе обучения. Абсолютно очевидно, что студент, который не познал самого себя, не может поставить перед собой четкие цели, двигаться к их достижению, что и приводят к соответствующему уровню успеваемости.

То, насколько успешным будет студент в процессе обучения, зависит от понимания своего собственного Я, т.е. осознания себя в полной мере - чувств, эмоций, желаний, ценностей, целей, возможностей и т.д.

Например, чрезмерная тревожность и, наоборот, самоуспокоенность не приводят к хорошей успеваемости. Уровень самооценки так же влияет на успеваемость. Слишком завышенная или заниженная самооценка оставляют студентов в числе отстающих. Необходимо помнить про степень адекватности во всех отношениях и проявлениях.

Конечно же и от уровня учебной мотивации зависит успешность обучения. Если у студентов недостаточный уровень учебной мотивации, который выражается в недооценке смысла или значения процесса обучения и его результата, отсутствует убеждение в пользе получаемого образования (Энциклопедический словарь по психологии и педагогике), то успешным такой студент не будет. Студент же с умеренно-высоким уровнем учебной мотивации обладает познавательными, моральными или профессиональными мотивами, которые бессознательно мотивируют достигать успеха и 
Научные труды Московского гуманитарного университета

2020 № 6

прогрессировать в образовательной среде (Факторы, влияющие..,, 2013).

В итоге мы можем предположить, что существует взаимосвязь уровня мотивации, ценностных ориентаций и успешного обучения, где ценности являются показателем направленности личности на получение знаний в выбранной области, а уровень мотивации - показатель способности реализации и достижения поставленных целей.

Ценность получения знания присуща больше целеустремленным студентам, истинно заинтересованным в саморазвитии и самообразовании, у таких студентов сильная воля и ясные ценности. В то время как ценность получения профессии присуща более избирательным студентам, которые в основном не испытывают жажду знаний, а делят их на полезные и бесполезные, где полезные - будут необходимы для их профессионального становления, и поэтому академическая успеваемость будет зависеть от количества полезных индивиду дисциплин. Чем их больше, тем выше уровень его успеваемости. Студенты с ценностью получения диплома нацелены зачастую на получение бумажки из университета, но не заинтересованы получением знаний, поэтому учатся крайне посредственно.

Опираясь на исследование психологических особенностей студентов, можно сделать вывод, что волевые качества личности играют одну из главнейших ролей в процессе обучения, выступают основным фактором успешной учебной деятельности.

Получается, что низкая и недостаточная мотивация не пророчит нам отсутствия успеха в будущем, а лишь показывает необходимость развивать мотивацию и волевые качества индивида, проявлять силу воли ради достижения цели, которая может обуславливаться социальной необходимостью.

Механизм волевого действия - это намеренные усиления мотивов и убеждения самих себя в необходимости выполнения определенных действий в пользу желаемого результата и ослабления мотивов конкурирующих действий. Подобный механизм может использовать сам студент, заставляя себя делать то, что не всегда нравится, или педагоги, влияя на внутреннее убеждение студента в пользу обучения, представления мотивов, которые могут откликнуться в сознании студента и сдвинуть мотивы на цель. Необходимо так же создать условия для возникновения познавательной потребности и познавательных интересов, делая процесс обучения интересным, вовлекая студента в дискуссии, помогая сформировывать мотивы и установки для благоприятного преодоления любых препятствий по достижению поставленной цели.

Мы предполагаем, что ценностные ориентации у современных студентов гуманитарных вузов связаны с их уровнем мотивации достижения успеха. Чтобы подтвердить или опровергнуть наше предположение мы планируем провести исследование с использованием следующих методик:

1. Методика «Ценностные ориентации» М. Рокича позволяет определить 
содержательную сторону направленности личности и составляет основу ее отношений к окружающему миру, к другим людям, к себе самой, основу мировоззрения и ядро мотивации жизненной активности, основу жизненной концепции и «философии жизни». М. Рокич различает два класса ценностей: терминальные - убеждения в том, что какая-то конечная цель индивидуального существования стоит того, чтобы к ней стремиться; инструментальные убеждения в том, что какой-то образ действий или свойство личности является предпочтительным в любой ситуации (Методика М.Рокича...).

2. «Опросник для оценки мотивации достижения» Элерса» предназначен для определения уровня мотивации к достижению цели к успеху (Методика диагностики личности...)

Результаты исследования позволят соотнести ценности студентов с их мотивацией, прогнозировать дальнейшее развитие личности и профессиональной деятельности будущих специалистов, наметить пути их совершенствования.

Мы предполагаем, что на первом месте у студентов гуманитарных вузов будут выявлены такие терминальные ценности, как здоровье, интересная работа, счастливая семейная жизнь, а на последнем - жизненная мудрость и активная деятельная жизнь.

Также мы предполагаем, что среди инструментальных ценностей на первых местах будут: образованность, ответственность, рационализм и аккуратность. В целом мы предполагаем, что большинство опрошенных будут иметь среднюю мотивацию.

Автор представит результаты исследования в своей выпускной квалификационной работе магистра ««Взаимосвязь ценностных ориентаций и мотивации достижения успеха студентов гуманитарного вуза».

\section{СПИСОК ЛИТЕРАТУРЫ}

Ансимова Н.П., Мишучкова Е.Ю. (2016) Ценностные ориентации и мотивация достижения студентов педагогического вуза [Электронный ресурс] //Ярославский педагогический вестник № 1. URL: https://cyberleninka.ru/article/n/tsennostnye-orientatsii-i-motivatsiya-dostizheniya-studentov-pedagogicheskogo-vuza/viewer. Дата обращения: 01.03.2020.

Борзилова Н.С. (2012) Динамика мотивационно-ценностных отношений в профессиональном становлении студентов // Молодой ученый. № 4 (39). С. 379381.

Иванников В.А. (1991) Психологические механизмы волевой регуляции. М., 1991. 1208 с.

Методика диагностики личности на мотивацию к успеху Т. Элерса. (Опросник T. Элерса для изучения мотивации достижения успеха) [Электронный ресурс]. URL: https://psycabi.net/testy/271-metodika-diagnostiki-lichnosti-na-motivatsiyu-k-us- 
pekhu-t-elersa-oprosnik-t-elersa-dlya-izucheniya-motivatsii-dostizheniya-uspekha. (дата обращения: 30.03.2020).

Методика М.Рокича «Ценностные ориентации» [Электронный ресурc]. URL: http://dip-psi.ru/psikhologicheskiye-testy/post/metodika-m-rokicha-tsennostnyye-oriyentatsii\#q1. (дата обращения: 30.03.2020).

Недостаточная мотивация. //Энциклопедический словарь по психологии и педагогике. [Электронный pecypc] URL: https://psychology_pedagogy.academic.ru (дата обращения 10.03.2020).

Олпорт Г. (2002) Становление личности: Избранные труды. М.: Смысл. 464 с.

Факторы, влияющие на успешность обучения студентов (2013). Студопедия. [Электронный ресурc] URL: https://studopedia.ru/11_146011_tema-faktori-vliyayushchie-na-uspeshnost-obucheniya-studentov.html (дата обращения: 20.03.2020).

Формы жизни: гуманитарная психология и этика личности (2014) / Эдуард Шпрангер. М.: Канон+, 399 с.

Милентьева Алена Сергеевна - обучающаяся 3 курса образовательной программы магистратуры по направлению подготовки 44.04.02 Психологопедагогическое образование Московского гуманитарного университета. Научный руководитель: В.Г. Тылец, доктор психологических наук, профессор кафедры фонетики и грамматики французского языка, Московский государственный лингвистический университет. Адрес: 111395, Россия, г. Москва, ул. Юности, д. 5. Тел.: +7 (499) 374-74-59. Эл. адрес: pp.mosgu@mail.ru

Milentyeva Alyona Sergeevna - 3-year student of the master's degree program in the field of training 44.04.02 Psychological and pedagogical education, Department of Pedagogy and Psychology of the Higher School of the Moscow humanitarian University. Scientific Adviser - V.G. Tylets, doctor of psychological sciences, professor, professor of the department of phonetics and grammar of the French language of the Moscow Linguistic University. Address: 5 Yunosti str., Moscow, 111395, Russia. Phone: +7 (499) 374-74-59. Email: pp.mosgu@mail.ru

\section{Для цитирования:}

Милентьева А.С. Проблема формирования мотивации достижений студентов гуманитарных вузов // Научные труды Московского гуманитарного университета. 2020. №6. C. 50-55. DOI: https://www.doi.org/10.17805/trudy.2020.6.9 